\title{
The Effect of Post-Heat Treatment in MDF Panels
}

\author{
Stefânia Lima Oliveira ${ }^{a}$, Ticyane Pereira Freire ${ }^{b}$, Lourival Marin Mendes $^{a}$, Rafael Farinassi Mendes ${ }^{a}$ \\ a Federal University of Lavras - UFLA, Lavras, MG, Brazil \\ ${ }^{b}$ University Center of Lavras - UNILAVRAS, Lavras, MG, Brazil
}

Received: March 29, 2016; Revised: October 17, 2016; Accepted: November 21, 2016

\begin{abstract}
This study was to evaluate the effect of post-heat treatment on the physical and mechanical properties of MDF (Medium Density Fiberboard) panels. Commercial MDF panels were produced in Brazil using Pinus wood and urea-formaldehyde (UF) adhesive. The post-heat treatments were carried in a factorial $3 \times 2$ (three temperatures of heat treatment $-200,225$ and $250{ }^{\circ} \mathrm{C}$, and two times -5 and 10 minutes), and a control treatment (without heat treatment). Subsequently, the physical and mechanical tests were performed. From the results it can be concluded that: 1) The most effective thermal post-treatment for improving the dimensional stability of the MDF was applied at $225^{\circ} \mathrm{C}$ and $10 \mathrm{~min}$; 2) All the thermally treated panels revealed a significant decrease in the modulus of rupture and modulus of elasticity (MOR and MOE) to bending when compared with the control panels without post-heat treatment.
\end{abstract}

Keywords: Physical and mechanical properties, Dimensional stability, Temperature and time of heat treatment, post-heat treatment, MDF panels

\section{Introduction}

The furniture industry combines several production processes, including a variety of raw materials and final products. It is chiefly the result of the materials the furniture is composed of (wood, metal and other), as well as related to the uses for which they are destined ${ }^{1,2}$.

The wood furniture, hold a significant percentage of the total industry production. It is segmented into two types: straight, having a smooth, with simple design of the straight lines using particleboard and plywood panels as the raw materials; and turned, combining more sophisticated finishing details, mixing both straight and curved shapes and utilizing whose main raw material is solid wood and panels Medium Density Fiberboard (MDF), which can be machined ${ }^{3}$.

The MDF panels are produced by wood fiber bonding, utilizing synthetic adhesives and the combined action of temperature and pressure ${ }^{4}$. To obtain the fibers, the wood is cut into small chips which are subsequently comminuted by shredders 5 . The MDF panels has excellent machining conditions, both at the edges as in the faces. When the correct density and homogeneity are provided by the fibers, the MDF panel can be easily turned, carved and machined ${ }^{6}$.

As already mentioned, this panel type widely use in the furniture sector, in particular, in front doors, drawer fronts and other more elaborate pieces ${ }^{7}$. However, for the employment of this panel in highly humid areas, improved dimensional stability is required, because this product will be in contact with water and / or water vapor on an everyday, in particular in bathrooms and kitchens, which involve the use of furniture made with MDF panels.

* e-mail: rafael.mendes@deg.ufla.br
Several possible alternatives have been proposed for improving the dimensional stability of the panels. They include heat treatment, which involves hemicellulose degredation, the most hygroscopic of the cell wall components, as well as the release of the compressive stresses formed during pressing $^{8,9}$.

A few studies have reported the influence of the heat treatment on the conventional particleboard, flakeboard, waferboard, MDF and OSB. They have shown promise, because normally the heat treatment of the previously consolidated panels enhances the dimensional stability and resistance to xylophagous attack ${ }^{9-14}$. However, heat treatment in the panels could also reduce the mechanical properties $^{10,15}$.

Thus, the aim of this study was to evaluate the effect of time and temperature level of post-heat treatment on the physical and mechanicals properties MDF panels, seeking to obtain a treatment that improves the dimensional stability of the panels with the least possible effect on the reduction of mechanical properties.

\section{Material and Methods}

\subsection{Obtaining the material}

Commercial MDF panels used were produced in Brazil using Pinus wood and urea-formaldehyde (UF) adhesive and with dimensions of $2.75 \times 1.83 \times 0.015 \mathrm{~m}$ (length, width and thickness, respectively). These panels were divided in smaller panels of $50 \times 50 \mathrm{~cm}$ (length and width, respectively), and which were conditioned in a room at $22 \pm 2{ }^{\circ} \mathrm{C}$ temperature and $65 \pm 5 \%$ relative humidity. 


\subsection{Post-heat treatment}

The panels were heat-treated in a hydraulic press, with time, temperature and pressure control, as specified in Table 1.

Table 1: Type of heat treatment.

\begin{tabular}{ccc}
\hline Treatment & Temperature $\left({ }^{\circ} \mathrm{C}\right)$ & Time (Min.) \\
\hline T1 & 200 & 5 \\
T2 & & 10 \\
T3 & 225 & 5 \\
T4 & & 10 \\
T5 & 250 & 5 \\
T6 & & 10 \\
Control & - & - \\
\hline
\end{tabular}

The pressure used for the post-heat treatment was 0.5 $\mathrm{kgf} / \mathrm{cm}^{2}$ to promote good contact between the press platens and the panel to facilitate temperature conduction. A duration of $10 \mathrm{~s}$ was employed for closing the press, the press was kept closed for 5 or 10 min according to each treatment, and a subsequent 10 -s duration was allowed to open the press. Three replicates for each treatment were performed.

\subsection{Physical and mechanical properties}

The panels after heat-treated were air-conditioned in a room with temperature of $22 \pm 2{ }^{\circ} \mathrm{C}$ and $65 \pm 5 \%$ relative humidity. The test bodies were obtained by using a standard saw. The dimensions of the test bodies and test procedures used for the evaluation of the properties of apparent density, water absorption after 2 and $24 \mathrm{~h}$ (WA2h and WA24h), thickness swell after 2- and 24-h immersion (TS2h and TS24h), irreversible thickness swelling rate (ITS), and internal bond (IB) were according to the determinations of the ASTM D1037 ${ }^{16}$ norm, while for the properties of the modulus of elasticity (MOE) and modulus of rupture (MOR) in static bending, the DIN $52362{ }^{17}$ norm was adopted. The bulk density of the panels was calculated using the average density of each of the samples in determining the physical and mechanical properties.

\subsection{Thermal property of the adhesive}

The thermal thermogravimetric analysis (TGA) was performed using a Shimadzu DTG-60AH device in which $2 \mathrm{mg}$ of each sample was subjected to a heating rate of $20^{\circ} \mathrm{C}$ $\mathrm{min}^{-1}$ at an initial temperature of $30^{\circ} \mathrm{C}$ and final temperature of $600^{\circ} \mathrm{C}$, under nitrogen flow. The analysis of differential scanning calorimetry (DSC) was done on a Shimadzu DSC apparatus 60A. It used $2 \mathrm{mg}$ of sample, Heating rate of $25^{\circ} \mathrm{C} \mathrm{min}{ }^{-1}$ under nitrogen flow, at an initial temperature of $30^{\circ} \mathrm{C}$ and final temperature of $350^{\circ} \mathrm{C}$. The analyzes were performed to assess the effect of post-heat treatment in the degradation property of the urea-formaldehyde adhesive, which may ultimately affect the final quality of the panel.

\subsection{Statistical analysis}

For statistical analysis of the data, the experiment was conducted in completely randomized design, in which the treatments were arranged in a $3 \times 2$ factorial arrangement (three temperatures of post-heat treatment $-200,225$ and $250^{\circ} \mathrm{C}$, and two times - 5 and 10 minutes) and a control treatment (without heat treatment). For comparison between the panels that had undergone some treatment and the control panels, Dunnett's test at 5\% significance was conducted. The Tukey test, also at $5 \%$ significance, was performed for the properties that showed significant interaction between the temperature and post-heat treatment time as well as for evaluating the bulk density, moisture and thickness of the panels.

\section{Results and Discussion}

\subsection{Bulk density, moisture and thickness}

In Table 2 it can be seen the average values of density, moisture and thickness of the post-heat treated panels.

For bulk density, only the panels subjected to heat treatment for $10 \mathrm{~min}$., except only treatment at $200^{\circ} \mathrm{C}$, differed statistically from the witness panels having lower mean values. According to Paul et al. ${ }^{15}$ e Mendes et al. ${ }^{9}$, the decrease in bulk density of the panels may be related to chemical degradation of some wood polymers, especially polyoses, and also the release of tensions of panels pressing.

Ayrilmis et al. ${ }^{14}$ evaluated the dimensional stability of the commercial MDF with phenol-formaldehyde adhesive and heat post-treatment. The panels were thermally treated at temperatures of $175^{\circ} \mathrm{C}$ for 15 minutes, $200^{\circ} \mathrm{C}$ for 30 minutes and $225^{\circ} \mathrm{C}$ for 30 minutes. The authors recorded mean values of bulk density ranging from 780 and $810 \mathrm{~kg}$ $\mathrm{m}^{-3}$, with a tendency for lowered values for the heat-treated panels, although it was not statistical difference between treatments.

Mendes et al. ${ }^{9}$ studied the effect of the thermal treatment of a particulate strand at temperatures of 200 to $240^{\circ} \mathrm{C}$, on the quality of the OSB, observed a significant reduction in the density panels. The authors also observed the direct effect of an increase in panel thickness on the decrease in the bulk density of the panels. This thickness in increase is due to the partial release of the compressive stress, which occurred just at the end of the pressing in panel production, a fact also observed in this study (Table 2).

The heat treatment at $250^{\circ} \mathrm{C}$ and 10 minutes showed the lowest average for moisture, differing significantly from the other treatments. while the control panels showed the higher mean value, differing significantly from the other 
Table 2: Average values of bulk density, moisture and thickness of the MDF panels.

\begin{tabular}{|c|c|c|c|}
\hline Treatment & $\begin{array}{l}\text { Bulk Density } \\
\left(\mathrm{kg} \cdot \mathrm{m}^{-3}\right)\end{array}$ & Moisture (\%) & $\begin{array}{l}\text { Thickness } \\
\text { (mm) }\end{array}$ \\
\hline $200^{\circ} \mathrm{C} 5^{\prime}$ & $630(0.02) b$ & $7.7(0.2) \mathrm{c}$ & $15.66(0.21) \mathrm{a}$ \\
\hline $200^{\circ} \mathrm{C} 10^{\prime}$ & $630(0.02) b$ & $7.0(0.2) b$ & $15.86(0.30) \mathrm{a}$ \\
\hline $225^{\circ} \mathrm{C} 5^{\prime}$ & $650(0.01)$ a & $6.9(0,1) b$ & $15.68(0.32) \mathrm{a}$ \\
\hline $225^{\circ} \mathrm{C} 10^{\prime}$ & $600(0.01) \mathrm{b}$ & $6.9(0.2) b$ & $15.74(0.29) \mathrm{a}$ \\
\hline $250^{\circ} \mathrm{C} 5^{\prime}$ & $657(0.00) \mathrm{a}$ & $6.9(0.02) b$ & $16.05(0.45) \mathrm{a}$ \\
\hline $250^{\circ} \mathrm{C} 10^{\prime}$ & $627(0.01) b$ & $6.6(0.1) \mathrm{a}$ & $15.68(0.24) \mathrm{a}$ \\
\hline Control & $680(0.01) \mathrm{a}$ & $8.2(0.07) \mathrm{d}$ & $15.25(0.17) \mathrm{a}$ \\
\hline
\end{tabular}

Means followed by the same letter in the column show no difference statistically by the Tukey test at the $5 \%$ significance level. The standard deviation values are given within the parentheses.

treatments. Also in relation to moisture, the treatments at $200^{\circ} \mathrm{C}$ in 10 minutes, $225^{\circ} \mathrm{C}$ in two times ( 5 and 10 minutes) and at $250^{\circ} \mathrm{C}$ in 5 minutes were statistically equal. All the average values for moisture content met the requirements of the NBR $15316-2^{18}$ and EN $622{ }^{19}$ standards, defining the minimum humidity at $4 \%$ and a maximum of $11 \%$.

\subsection{Physical properties}

Table 3 lists the average values of water absorption after two (AA2h) and after twenty-four hours (AA24h) for each of the treatments evaluated. Variations in the average values of the panels in relation to the panels without heat treatment are also shown.

Table 3: Average values water absorption values of the MDF after two and twenty-four hours of immersion.

\begin{tabular}{|c|c|c|c|c|}
\hline Treatment & \multicolumn{4}{|c|}{$\%$} \\
\hline $200^{\circ} \mathrm{C} 5^{\prime}$ & $7.5(1.2) \mathrm{ns}$ & -13.0 & $23.5(1.4) \mathrm{ns}$ & -26.0 \\
\hline $200^{\circ} \mathrm{C} 10$ & $7.3(0.4) \mathrm{ns}$ & -18.2 & $22.8(1.9) *$ & -28.0 \\
\hline $225^{\circ} \mathrm{C} 5^{\prime}$ & $6,5(0.8) \mathrm{ns}$ & -24.7 & $20.0(2.0) *$ & -36.8 \\
\hline $225^{\circ} \mathrm{C} 10^{\prime}$ & $3.8(0.6) *$ & -55.8 & $12.2(1.7) *$ & -61.6 \\
\hline $250^{\circ} \mathrm{C} 5^{\prime}$ & $16.8(3.0) *$ & 95.5 & $35.4(4.7) \mathrm{ns}$ & 11.7 \\
\hline $250^{\circ} \mathrm{C} 10^{\prime}$ & $22.9(4.3) *$ & 166.5 & $41.0(5.0) *$ & 29.2 \\
\hline Control & $8.6(1.9)$ & & $31.7(6.0)$ & \\
\hline
\end{tabular}

* Differs statistically by Dunnett's test ( $\alpha=00: 05)$ from the control treatment; ns does not differ statistically by Dunnett's test $(\alpha=$ 00:05) from the control treatment. Standard deviation values are given within parentheses.

It can be seen that only the panels heat-treated at $225^{\circ} \mathrm{C}$ for $10 \mathrm{~min}$. and the panels heat-treated at $250^{\circ} \mathrm{C}$ in two stages ( 5 and 10 minutes) differed significantly of the panels without thermal treatment.

The heat treatment at $225^{\circ} \mathrm{C}$ and $10 \mathrm{~min}$. improved the AA2h property, getting the lowest average, with decrease of $-55.8 \%$. However, the panels treated at $250^{\circ} \mathrm{C}$ in two stages, showed an increase in the AA2h, with increased of 95.5 and $166.5 \%$, respectively.

For the AA24h property, only those panels treated at $200^{\circ} \mathrm{C}$ and $250^{\circ} \mathrm{C}$ at the time of 5 minutes, showed no statistical difference from the panels without thermal treatment. The other treatments revealed a reduction in this property, except for the treatment at $250^{\circ} \mathrm{C}$ and 10 minutes, which showed an increase of $29.2 \%$.

Gonçalez et al. ${ }^{20}$ studied the heat treatment of MDF panels at temperatures of 160 to $180^{\circ} \mathrm{C}$ and times of 15 and 30 minutes and observed a significant reduction in water absorption after 24 hours of immersion in the order of $-65 \%$. Ayrilmis et al. ${ }^{14}$ evaluated the dimensional stability of the MDF post-heat treatment. The panels were thermally treated at $175^{\circ} \mathrm{C}$ for 15 minutes, $200^{\circ} \mathrm{C}$ for 30 minutes and $225^{\circ} \mathrm{C}$ for 30 minutes. The authors observed a reduction of the values for AA2h from -1.8 to $-7.7 \%$ and AA24h reduction between -28.6 to $-5.0 \%$.

This decrease of the hygroscopicity is due to because reduced accessibility to the sorption sites and the formation of furfural polymers, resulto of the sugars degradation (hemicelluloses), which are less hygroscopic ${ }^{21}$. Winandy e Krzysik $^{13}$ conducted heat treated in fibers to produce MDF panels at temperatures of 180,200 and $220^{\circ} \mathrm{C}$ and detected a reduction in the arabinan and galactan content, both components of the side chain of the hemicelluloses. The manana, a key component of main chain of hemicellulose, was also affected, although to a lesser degree. These authors purported that these changes in the hemicellulose appeared to lower the hygroscopicity of the fibers. This in turn inhibits moisture sorption, which could lead to water absorption, thickness swelling and influences the loss of mechanical properties.

Still in relation to the data obtained, it was observed interaction between the three temperatures $\left(200225250^{\circ} \mathrm{C}\right)$ and the two times of use ( 5 and 10 minutes) for AA2h and AA24h properties as shown in Table 4.

On evaluation of the AA $2 \mathrm{~h}$ property using different times of thermal treatment ( 5 and 10 minutes) in each different temperature $\left(200,225\right.$ and $\left.250^{\circ} \mathrm{C}\right)$, it was observed that at both times the treatment at $250^{\circ} \mathrm{C}$ statistically differed from the others, revealing the highest average value. For AA24h, in the time of 5 minutes was there any statistical difference observed only for the treatment at $250^{\circ} \mathrm{C}$; however, for 10 minutes, all the treatments showed statistical diferences, in both cases with the highest values being obtained for those panels heated to $250^{\circ} \mathrm{C}$.

In evaluation each temperature $\left(200,225\right.$ and $\left.250^{\circ} \mathrm{C}\right)$ within each time ( 5 and 10 minutes), only for $\mathrm{AA} 2 \mathrm{~h}$ no statistical difference was recorded in temperature to $250^{\circ} \mathrm{C}$, for $\mathrm{AA} 2 \mathrm{~h}$ was statistical difference only in temperature to $250{ }^{\circ} \mathrm{C}$, increasing the average value with the addition of time of post-heat treatment. However, for AA24h only treatment at $225^{\circ} \mathrm{C}$ was statistically different from other 
Table 4: Deployments of average values of water absorption after two and twenty-four hours based on the time and temperature of MDF.

AA2h $(\%)$

Temperature $\left({ }^{\circ} \mathrm{C}\right)$
AA24h (\%)

Time

\begin{tabular}{ccccc} 
& $5^{\prime}$ & $10^{\prime}$ & $5^{\prime}$ & $10^{\prime}$ \\
\hline 200 & $7.5^{(1.2)} \mathrm{bA}$ & $7.3^{(0.6)} \mathrm{bA}$ & $23.5^{(1.4)} \mathrm{bA}$ & $22.8^{(1.7)} \mathrm{bA}$ \\
225 & $6.5^{(0.4)} \mathrm{bA}$ & $3.8^{(3.0)} \mathrm{bA}$ & $20.0^{(1.9)} \mathrm{bA}$ & $12.2^{(4.7)} \mathrm{cB}$ \\
250 & $16.8^{(0.8)} \mathrm{aB}$ & $22.9^{(4.3)} \mathrm{aA}$ & $35.4^{(2.0)} \mathrm{aA}$ & $41.0^{(5.0)} \mathrm{aA}$
\end{tabular}

Means followed by the same letter show no statistical difference by the Tukey test at $5 \%$ significance level. Lower case letters refer to the values of the columns while the capitals refer to the values of the lines. The standard deviation values are given within the parentheses.

treatments, reducing the average value with increasing heat treatment time.

The highest average values obtained for the panels thermally treated at $250^{\circ} \mathrm{C}$, at both times, may be associated with the greater thermal depolymerization of the cellulose, occurs between the temperatures of 200 to $280{ }^{\circ} \mathrm{C}^{22}$, and it is steeper from $240^{\circ} \mathrm{C}^{23}$. It is also associated with the fact that the urea-formaldehyde adhesive gets degraded at this temperature as shown in Figure 1, where the onset of the degradation of the adhesive at temperature $250^{\circ} \mathrm{C}$ is observed, which promotes the reduction of bonding between the particles, as well as enables greater thickness swelling (Table 5), resulting in an increase in the internal spaces within the panel and consequently greater water absorption capacity.

Table 5 shows the mean values of thickness swelling after two (IE2h) and after twenty-four hours (IE24h) and the rate of no return in thickness (TNRE) for each treatment tested. Variations in the average values of the panels in relation to the panels without heat treatment are also shown.

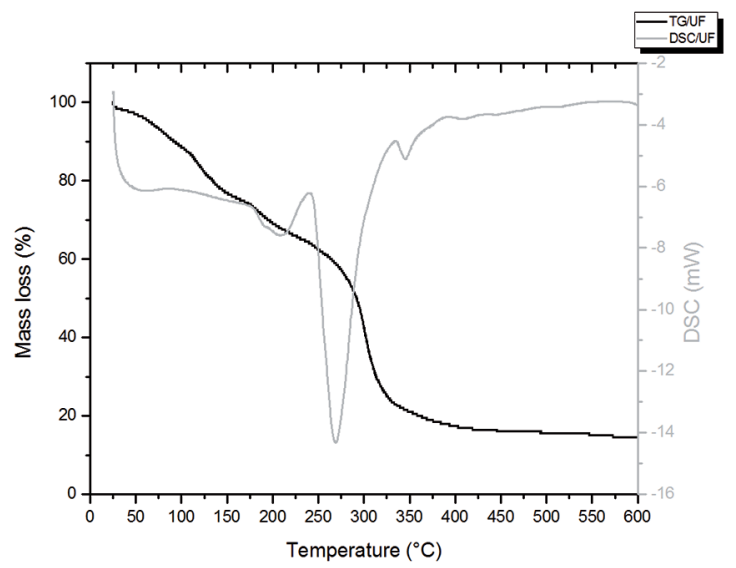

Figure 1: Mass loss of the urea formaldehyde adhesive as a function of temperature.

On evaluating the IE2h property, only those panels treated at $250^{\circ} \mathrm{C}$ and $5 \mathrm{~min}$ showed no statistical difference from the panels without heat treatment. Treatments at temperatures of 200 and $225^{\circ} \mathrm{C}$ at both times ( 5 and 10 minutes) reduced IE2h, ranging from -43.5 to $-87.1 \%$. While the treatment at $250^{\circ} \mathrm{C}$ for 10 minutes time, also differed statistically from the control panel,however, an increase of $82.3 \%$ in this property. Fact that associated with the thermal degradation of the urea-formaldehyde adhesive, as previously discussed (Figure 1).

For the IE24h and TNRE properties the treatments at $200^{\circ} \mathrm{C}$ in both heat treatments ( 5 and 10 minutes) and at $250^{\circ} \mathrm{C}$ in 10 minutes of time there was no difference statistically from the control panels. The panels treated at $225^{\circ} \mathrm{C}$ in two times ( 5 and 10 minutes) obtained reduction of -24.9 and $-62.4 \%$ for IE24h and -35.3 and $-72.1 \%$ for TNRE, respectively. The panels treated at $250{ }^{\circ} \mathrm{C}$ and 5 minutes showed increases in these properties of 24.9 and $32.4 \%$, respectively.

These smaller average values for thickness swelling and rate of no return in thickness, were observed mostly in the treatments applied at $225^{\circ} \mathrm{C}$, are associated with two factors: 1) chemical modification of the panel surface; and 2) release of pressing tension ${ }^{9}$. On the issue of chemical modification, chemical degradation of the hemicellulose is the main mechanism, compound less stable thermally and more hygroscopic. At first the hemicelluloses are broken down into monomeric structures and subsequently dehydrated to aldehydes to form the furfural when derived from pentose and hydroxymethylfurfural when derived from hexoses, lowering the hygroscopic capacity of the material ${ }^{24,25,13}$. However, it can also be associated with an increase in the crystalline portions, which induces a decrease in the amorphous regions of the cellulose microfibrils ${ }^{23-26}$.

In the case of release of pressing tensions, they develop during the panel production process, result of the fiber mattress compression, and then are retained in the consolidated panel by the action of the adhesive bond between the fibers, which are released when the panel is in contact with moisture and / or water. Practically, the heat treatment promovetes this release of pressing tensions, before the panels come into contact with moisture, which prevents partly the thickness swelling when in use ${ }^{9}$.

The release mechanism of compressive stress is described by Del Menezzi ${ }^{10}$, as the viscoelastic behavior of wood, mainly that of the lignin, that with the increased temperature applied to the panel, causes the matrix formed by the cross wood polymers have lower resistance to deformation, enables the internal stress to be released or minimized through a matrix rearrangement. 
Also in relation to data, interaction was observed between temperatures $\left(200,225\right.$ and $\left.250^{\circ} \mathrm{C}\right)$ and the two times of heat treatments ( 5 and 10 minutes). The deployments of the data for thickness swelling after two and twenty-four hours of immersion in water and the rate of no return in thickness are shown in Table 6 .

For IE2h and IE24h, evaluated the times of 5 and 10 minutes within each temperature $\left(200,225\right.$ and $\left.250^{\circ} \mathrm{C}\right)$. Note that in the time of 5 minutes only the treatment at $250^{\circ} \mathrm{C}$ differed significantly from the others, showing the highest average value. For the 10 minutes time period, the IE2h property, showed that three treatments were statistically different, with the lower value being obtained at $225^{\circ} \mathrm{C}$ and the highest at $250^{\circ} \mathrm{C}$. For the 10 minute time, in the IE24h property, only the treatment at $225^{\circ} \mathrm{C}$ was statistically distinct from the others $\left(200\right.$ and $\left.250^{\circ} \mathrm{C}\right)$, revealing the lowest average value. In relaction of the TNRE, in two time periods ( 5 and 10 minutes), the three treatments showed statistical differences, with the highest value being observed for the temperature of $250^{\circ} \mathrm{C}$ and the lowest value being observed for $225^{\circ} \mathrm{C}$.

On analyzing each temperature $\left(200,225\right.$ and $\left.250^{\circ} \mathrm{C}\right)$ within each time ( 5 and 10 minutes), there was significant effect for IE2h only when analyzed treatment at $250^{\circ} \mathrm{C}$, the highest value was obtained at time $10 \mathrm{~min}$. For IE24h, there was a difference between the treatment only at 225 ${ }^{\circ} \mathrm{C}$ temperatures, the lowest value being obtained at 10 min. For the TNRE, there was a significant effect of time at temperatures of $225^{\circ} \mathrm{C}$ and $250^{\circ} \mathrm{C}$; at $225^{\circ} \mathrm{C}$ with increasing time there was a reduction of the mean value, while at the $250^{\circ} \mathrm{C}$ temperature the increase in the time gave a higher average value.

Thus, there is a generallly that the best post-heat treatment for improving the dimensional stability of MDF is at $225^{\circ} \mathrm{C}$ and time of $10 \mathrm{~min}$. As it has been observed, post-heat treatment at higher temperatures is not indicated.

Ayrilmis et al. ${ }^{14}$ evaluated the effect of heat treatment on the dimensional stability of the MDF made with phenol formaldehyde adhesive. The panels were thermally treated at $175^{\circ} \mathrm{C}$ for 15 minutes, $200^{\circ} \mathrm{C}$ for 30 minutes and $225^{\circ} \mathrm{C}$ for 30 minutes. The authors observed a decrease for IE2h in the order of 0.9 to $7.4 \%$ and for the IE24h in the order of $-1.5 \%$ to -14.6 .

Mohebby e Ilbeighi ${ }^{27}$ evaluated MDF panels composed of industrial fibers and treated hydrothermally at 120, 150 and $180^{\circ} \mathrm{C}$ for a time of 0,30 and $90 \mathrm{~min}$. The MDF panels were produced with $0.70 \mathrm{~g} / \mathrm{cm}^{3}$ density, $10 \mathrm{~mm}$ thickness and a $3 \mathrm{MPa}$ pressure pressing cycle, at $170^{\circ} \mathrm{C}$ and 10 minutes of time. The authors noted a decrease in the thickness swelling after two hours and twenty four hours (IE2h and IE24h) in response to the increase in temperature and time. For IE2h, the reductions observed were of the order of -4 to $-38 \%$, while for the IE $24 \mathrm{~h}$ the reductions were of the order of -10 to $-36 \%$.

According to ANSI A208.2 28 , the maximum value of thickness swelling for the MDF panels in internal use applications is $10 \%$. Thus, only those panels heat treated at $225^{\circ} \mathrm{C}$, in two times, met this prerequisite. However, with the norm EN $622^{19}$, which reveals a maximum of $12 \%$ for panels with a nominal thickness of 12 to $19 \mathrm{~mm}$, only the

Table 5: Average values of the swelling thickness of the MDF after two and twenty-four hours of immersion and the thickness no return rate.

\begin{tabular}{ccccccc}
\hline Treatment & IE2h & $\Delta$ & IE24h & $\Delta$ & TNRE & $\Delta$ \\
\hline $200^{\circ} \mathrm{C} 5^{\prime}$ & $3.5(0.7)^{*}$ & -43.5 & $11.3(1.2) \mathrm{ns}$ & -7.8 & $6.3(1.0) \mathrm{ns}$ & -7.4 \\
$200^{\circ} \mathrm{C} 10^{\prime}$ & $3.2(0.6)^{*}$ & -48.4 & $11.4(1.1) \mathrm{ns}$ & -6.9 & $5.6(0.6) \mathrm{ns}$ & -17.6 \\
$225^{\circ} \mathrm{C} 5^{\prime}$ & $2.4(0.2)^{*}$ & -61.3 & $9.2(0.8) *$ & -24.9 & $4.4(0.6)^{*}$ & -35.3 \\
$225^{\circ} \mathrm{C} 10^{\prime}$ & $0.8(0.3)^{*}$ & -87.1 & $4.6(0.5) *$ & -62.4 & $1.9(0.6)^{*}$ & -72.1 \\
$250^{\circ} \mathrm{C} 5^{\prime}$ & $7.2(1.2) \mathrm{ns}$ & 16.1 & $15.3(2.0)^{*}$ & 24.9 & $9.0(1.3) *$ & 32.4 \\
$250^{\circ} \mathrm{C} 10^{\prime}$ & $11.3(2.2)^{*}$ & 82.3 & $13.8(1.4) \mathrm{ns}$ & 12.65 & $7.4(0.8) \mathrm{ns}$ & 8.8 \\
Control & $6.2(1.0)$ & & $12.25(0.4)$ & & $6.8(0.4)$ & \\
\hline
\end{tabular}

* Differs statistically by Dunnett's test $(\alpha=00: 05)$ from the control treatment; ns does not differ statistically by Dunnett's test $(\alpha=00: 05)$ from the control treatment. The standard deviation values are given within parentheses.

Table 6: Deployments of average values of thickness swelling after two and twenty-four hours and the rate of no return in thickness based on the time and temperature of the thermal treatment of MDF.

\begin{tabular}{ccccccc}
\hline $\begin{array}{c}\text { Temperature } \\
\left({ }^{\circ} \mathrm{C}\right)\end{array}$ & \multicolumn{3}{c}{ IE2h (\%) } & \multicolumn{2}{c}{ IE24h (\%) } \\
& 5 & $10^{\prime}$ & 5 & \multicolumn{2}{c}{ Time } & \multicolumn{2}{c}{ TNRE (\%) } \\
\hline 200 & $3.5^{(0.7)} \mathrm{bA}$ & $3.2^{(0.3)} \mathrm{bA}$ & $11.3^{(1.2)} \mathrm{bA}$ & $11.4^{(0.5)} \mathrm{aA}$ & $6.3^{(1.1)} \mathrm{bA}$ & $5.6^{(0.6)} \mathrm{bA}$ \\
225 & $2.4^{(0.6)} \mathrm{bA}$ & $0.8^{(1.2)} \mathrm{cA}$ & $9.2^{(1.1)} \mathrm{bA}$ & $4.6^{(2.0)} \mathrm{bB}$ & $4.4^{(0.6)} \mathrm{cA}$ & $1.8^{(1.3)} \mathrm{cB}$ \\
250 & $7.2^{(0.2)} \mathrm{aB}$ & $11.3^{(2.2)} \mathrm{aA}$ & $15.3^{(0.8)} \mathrm{aA}$ & $13.8^{(1.4)} \mathrm{aA}$ & $9.0^{(0.6)} \mathrm{aA}$ & $7.4^{(0.8)} \mathrm{aB}$ \\
\hline
\end{tabular}

Means followed by the same letter show no statistical difference by the Tukey test at $5 \%$ significance level. Lower case letters refer to the values of the columns while the capitals refer to the values of the lines. The standard deviation values are given within the parentheses. 
panels treated at 200 and $225^{\circ} \mathrm{C}$ in two stages obtained the mean values below those stipulated by the standard.

\subsection{Mechanical properties}

Table 7 shows the mean values for the modulus of elasticity (MOE) and modulus of rupture (MOR) at static bending and internal bond for each of the treatments evaluated. The variations in the average values of the panels in relation to the panels without thermal treatment are also evident.

The mean values for the thermally treated panels, for MOR and MOE, were statistically distinct from the control panels, showing reductions of -10.3 to $-20.9 \%$ for MOE and -15.3 to $-40.7 \%$ for the MOR. For the internal bond property, only treatments 200 and $225^{\circ} \mathrm{C}$ in five minutes of time did not show statistical difference from the control panels; however, all the other treatments showed a reduction in this property, in the order of -11.9 to $-373 \%$.

According Ayrilmis et al. ${ }^{14}$ and Mendes et al. ${ }^{9}$ the reduction of the MOE and MOR can be attributed in part to the fact that the heat treatment have caused mass loss during heating, as well as released the tensions of pressing, consequently decreasing the panel density, which relates positively to the mechanical properties of the panel ${ }^{29,30}$. However, Rowell ${ }^{31}$ suggests a few depolymerization steps of the carbohydrates by the acids which are produced by the chemical degradation of the timber, a fact that acelerates the breakdown of the long chain carbohydrates to shorter chains. This depolymerization and reduction of the cellulose polymer can affect the MOE and MOR timber, and under acidic conditions at elevated temperatures, it can degrade via hydrolysis, and thus affect the resistance of the wood.

It is also observed that the decreasing trend of the MOE is less than the decrease of MOR, which was also observed by several authors ${ }^{9,10,15,32}$.

Mohebby e Ilbeighi ${ }^{27}$ evaluated panels composed of MDF fibers hydrothermally treated at temperatures of 120,150 and $180^{\circ} \mathrm{C}$ for 0,30 and $90 \mathrm{~min}$. These panels were produced with $0.70 \mathrm{~g} / \mathrm{cm}^{3}$ density, $10 \mathrm{~mm}$ thickness and with a $3 \mathrm{MPa}$ pressure pressing cycle, at $170^{\circ} \mathrm{C}$ in $10 \mathrm{~min}$. The authors observed a reduction in the MOR, MOE and internal bond, as the temperature and time increased. For the MOR, the reductions observed were in the order of -6.3 to $-25.0 \%$, while for the MOE the reductions were approximately 9.1 to $20.5 \%$ and for the internal bond the reductis were in the order of -25.0 to $-43.8 \%$.

Jarusombuti et al. ${ }^{33}$ evaluated the physical and mechanical properties of the MDF panels made with Eucalyptus camaldulensis wood fibers heat treated at three different temperatures $\left(120^{\circ} \mathrm{C}, 150^{\circ} \mathrm{C}\right.$ and $\left.180^{\circ} \mathrm{C}\right)$ for 30 or 60 minutes using a laboratory autoclave. Regarding the mechanical properties, the authors observed a decrease of $-9 \%$ to -25 for the modulus of elasticity (MOE), of -16 to $-37 \%$ for the modulus of rupture (MOR) and -10 to $-39 \%$ for the internal bond.

The EN $622{ }^{19}$ standard has a minimum requirement of $20 \mathrm{MPa}$ for the MOR, $2200 \mathrm{MPa}$ for the MOE and 0.55 $\mathrm{MPa}$ for the internal bond. The ANSI-A 208.2 ${ }^{28}$ determines the minimum values of $24 \mathrm{MPa}$ for the MOR, of $2400 \mathrm{MPa}$ for the MOE and $0.60 \mathrm{MPa}$ for internal bond. Thus, none of the treatments (including the panels not subjected to the heat treatment) responded to the minimum internal bond stipulated by the EN $622^{19}$ and ANSI-A 208.2 28 standard. When considering the MOR, only the panels heat treatment at $250^{\circ} \mathrm{C}$ in 10 minutes did not meet the value set by the EN $622^{19}$ standard, while that for the ANSI-A 208.2 $2^{28}$, treatments at $225^{\circ} \mathrm{C}$ and 10 minutes and $250^{\circ} \mathrm{C}$ in two times $(5$ and 10 minutes) did not meet this minimum requirement. Regarding the MOE, all the treatments met the minimum value stipulated by the two standards.

No interaction was observed between the temperatures and times used for the mechanical properties of the panels. Tables 8 and 9 show the average values of MOE, MOR and IB in function of temperature and time of post-heat treatment, respectively.

Table 8 shows, when the mechanical properties were measured in function of temperature, only the MOR property was observed to have different average values for the three temeratures $\left(200,225\right.$ and $\left.250^{\circ} \mathrm{C}\right)$; a decrease in these values was noted as the temperature was increased to perform the heat treatment. The reason is that a greater reduction in the MOR values is associated with $250^{\circ} \mathrm{C}$, besides the improved chemical degradation of wood at the beginning of thermal

Table 7: Average values of the modulus of elasticity and modulus of rupture in bending strength and internal bond of the MDF panels.

\begin{tabular}{|c|c|c|c|c|c|c|}
\hline \multirow[t]{2}{*}{ Treatment } & MOE & $\Delta$ & MOR & $\Delta$ & Internal Bond & $\Delta$ \\
\hline & \multicolumn{6}{|c|}{$\mathrm{MPa}$} \\
\hline $200^{\circ} \mathrm{C} 5^{\prime}$ & $2847.5(112.1) *$ & -10.5 & $28.3(0.05) *$ & -15.3 & $0.41(0.03) \mathrm{ns}$ & -11.9 \\
\hline $200^{\circ} \mathrm{C} 10^{\prime}$ & $2630.1(112.1) *$ & -17.4 & $25.5(0.05) *$ & -23.7 & $0.33(0.04) *$ & -28.2 \\
\hline $225^{\circ} \mathrm{C} 5^{\prime}$ & $2853.7(123.5) *$ & -10.3 & $26.5(0.8) *$ & -20.7 & $0.36(0.05) \mathrm{ns}$ & -23.1 \\
\hline $225^{\circ} \mathrm{C} 10^{\prime}$ & $2595.6(49.3) *$ & -18.4 & $21.9(1.6) *$ & -34.4 & $0.29(0.03) *$ & -37.3 \\
\hline $250^{\circ} \mathrm{C} 5^{\prime}$ & $2637.6(70.0) *$ & -17.1 & $22.8(0.3) *$ & -31.7 & $0.32(0.07) *$ & -30.8 \\
\hline $250^{\circ} \mathrm{C} 10^{\prime}$ & $2516.7(27.2) *$ & -20.9 & $19.8(2.0) *$ & -40.7 & $0.30(0.09) *$ & -36.4 \\
\hline Control & $3182.3(38.0)$ & & $33.4(1.07)$ & & $0.47(0.03)$ & \\
\hline
\end{tabular}

* Differs statistically by Dunnett's test $(\alpha=00: 05)$ from the control treatment; ns does not differ statistically by Dunnett's test $(\alpha=00: 05)$ from the control treatment. The standard deviation values are given within parentheses. 
Table 8: Average values of MOE, MOR and Internal Bond based on the temperature applied to the MDF

\begin{tabular}{cccc}
\hline Temperature $\left({ }^{\circ} \mathrm{C}\right)$ & MOE & $\begin{array}{c}\text { MOR } \\
\text { MPa }\end{array}$ & Internal Bond \\
\hline 200 & $2738.8^{(159.0)} \mathrm{a}$ & $26.9^{(1.6)} \mathrm{a}$ & $0.37^{(0.1)} \mathrm{a}$ \\
225 & $2724.7^{(151.4)} \mathrm{a}$ & $24.2^{(2.7)} \mathrm{b}$ & $0.33^{(0.1)} \mathrm{a}$ \\
250 & $2577.1^{(72.5)} \mathrm{a}$ & $21.3^{(2.1)} \mathrm{c}$ & $0.31^{(0.1)} \mathrm{a}$ \\
\hline
\end{tabular}

Means followed by the same letter in the column show no statistical difference by the Tukey test at 5\% significance level. The standard deviation values are given within the parentheses.

Table 9: Average values for MOE, MOR and Internal Bond in function of the time of the heat treatment applied to the MDF.

\begin{tabular}{cccc}
\hline Time (min.) & MOE & $\begin{array}{c}\text { MOR } \\
\text { MPa }\end{array}$ & Internal Bond \\
\hline 5 & $2779.6^{(123.6)} \mathrm{a}$ & $25.9^{(2.8)} \mathrm{a}$ & $0.36^{(0.1)} \mathrm{a}$ \\
10 & $2580.8^{(89.1)} \mathrm{b}$ & $22.4^{(2.6)} \mathrm{b}$ & $0.31^{(0.1)} \mathrm{b}$ \\
\hline
\end{tabular}

Means followed by the same letter in the column show no statistical difference by the Tukey test at 5\% significance level. The standard deviation values are given within the parentheses.

degradation of the urea-formaldehyde adhesive (Figure 1), fact that promoted reduction trend of the internal bond of the panels (Table 8) and consequently the loss of the MOR flexure resistance.

Regarding the evaluation of the mechanical properties as a function of time (Table 9), a statistical difference is seen between the values at 5 and 10 minutes for the three properties evaluated, showing a decrease in the average values with increasing heat treatment time.

\section{Conclusions}

The most effective thermal post-treatment for improving the dimensional stability of MDF was applied at the temperature of $225^{\circ} \mathrm{C}$ and time of $10 \mathrm{~min}$. With this treatment smaller values were obtained for the AA2h, AA24h, IE24h and TNRE.

The thermal treatment at $250^{\circ} \mathrm{C}$ is not indicated for MDF made with urea-formaldehyde adhesive. This fact is due to the onset of thermal degradation of the adhesive and consequently increase in values of the physical and lower mechanical properties.

Only thermally treated panels at $225^{\circ} \mathrm{C}$ in two times ( 5 and $10 \mathrm{~min}$ ) meet the IE24h maximum value stipulated by ANSI A208.2 (2002) standard. The panels treated at 200 and $225^{\circ} \mathrm{C}$ in two times (5 and $10 \mathrm{~min}$ ) met the requirement of EN 622 (2006) standard for IE24h.

All the heat-treated panels revealed a significant decrease in the MOR and MOE in static bending when compared with the panels not subjected to thermal treatment. There was effect of temperature level only for the MOR propertywith the decrease in the average values according to the increased temperature levels. The effect of post-heat treatment time was also observed, with significantly decrease the properties of MOR, MOE and the internal bond with increase in the heat treatment time.

\section{Acknowledgement}

The author thank to the Fundação de Amparo à Pesquisa do estado de Minas Gerais (FAPEMIG), Conselho Nacional de Desenvolvimento Científico e Tecnológico (CNPq) and the Graduate Program in Biomaterials Engineering from the Federal University of Lavras / UFLA.

Conflict of interest: The authors declare that they have no conflicts of interest.

\section{References}

1. Bai Y, Gao Z. The ambient aging of wood fiber and its effect on mechanical properties of MDF panels. Wood Science and Technology. 2011;45(3):501-510.

2. Oliveira SL. Painéis aglomerados de bagaço de cana de açúcar: caracterização visando ao uso na indústria moveleira. [Dissertation]. Lavras: Universidade Federal de Lavras; 2013.

3. Gorini APF. Panorama do setor moveleiro no Brasil, com ênfase na competitividade externa a partir do desenvolvimento da cadeia industrial de produtos sólidos de madeira; 2013. Available from: $<$ http://www.bndespar.gov.br/SiteBNDES/export/sites/default/ bndes_pt/Galerias/Arquivos/conhecimento/bnset/set801.pdf>. Access in: 25/08/2015.

4. Xavier J, Belini UL, Pierron F, Morais J, Lousada J, Tomazello M. Characterisation of bending stiffness components of MDF panels from full-field slope measurements. Wood Science and Technology. 2013;47(2):423-441.

5. Rosa SES, Correa AR, Lemos MLF, Barroso DV. O setor de móveis na atualidade: uma análise preliminar; 2013. Available from: $<$ http://www.bndespar.com.br/SiteBNDES/export/sites/default/ bndes_pt/Galerias/Arquivos/conhecimento/bnset/set2503.pdf $>$. Access in: 25/08/2015.

6. Indústria Brasileira de Árvores. [acesso 2016 Dez 16]. Available from: < http://iba.org/pt/9-conteudo-pt/588-mdf-mediumdensity-fiberboard-paineis-de-fibra-de-media-densidade $>$. Access in: 05/12/2016. 
7. Torquato LP. Caracterização dos painéis MDF comerciais produzidos no Brasil. [Dissertation]. Curitiba: Universidade Federal do Paraná; 2008.

8. Del Menezzi CHS, Tomaselli I, Souza MR. Avaliação não-destrutiva de painéis OSB modificados termicamente: parte 1, efeito do tratamento térmico sobre a velocidade de propagação de ondas de tensão. Scientia Forestalis. 2007;76:67-75.

9. Mendes RF, Bortoletto Júnior G, Almeida NF, Surdi PG, Barbeiro IN. Effect of thermal treatment on properties of OSB panels. Wood Science and Technology. 2013;47(2):243-256.

10. Del Menezzi CHS. Estabilização dimensional por meio do tratamento térmico e seus efeitos sobre as propriedades de painéis de partículas orientadas (OSB). [Thesis]. Curitiba: Universidade Federal do Paraná; 2004. 242 p.

11. Del Menezzi CHS, Tomaselli I. Contact thermal post-treatment of oriented strandboard to improve dimensional stability: A preliminary study. Holz als Roh- und Werkstoff. 2006;64:212-217.

12. Okino EYA, Andahur JPV, Santana MAE, Souza MR. Resistência fisico-mecanica de chapas aglomeradas de bagaco de canade-acucar modificado quimicamente. Scientia Forestalis. 1997;52:35-42.

13. Winandy JE, Krzysik AM. Thermal degradation of wood fibers during hot pressing of MDF composites: Part I. Relative effects and benefits of thermal exposure. Wood and Fiber Science. 2007;39(3):450-461.

14. Ayrilmis N, Laufenberg TL, Winandy JE. Dimensional stability and creep behavior of heat-treated exterior medium density fiberboard. European Journal of Wood and Wood Products. 2009(67):287-295.

15. Paul W, Ohlmeyer M, Leithoff $H$. Thermal modification of OSB-strands by a one-step heat pre-treatment - Influence of temperature on weight loss, hygroscopicity and improved fungal resistance. Holz als Roh- und Werkstoff. 2007;65:57.

16. American Society For Testing and Materials. ASTM D 1037. Standard test methods for evaluating properties of wood-base fiber and particle panel materials. Philadelphia: ASTM;2006. $30 \mathrm{p}$.

17. DIN - Normen Für Holzfaserplatenspanplatten Sperrholz. DIN 52362. Testing of wood chipboards, bending test, determination of bending strength. Berlin: DIN; 1982. p. 39-40.

18. ABNT - Associação Brasileria de Normas Técnicas. NBR 153162. Chapas de fibras de média densidade. Parte 2: Requisitos. Rio de Janeiro: ABNT; 2006.

19. European Committee for Standardization. European Standard EN 622. Tableros de fibras-Especificaciones. Parte 5: Requisitos de los tableros de fibras fabricados por proceso seco. Bruxelas: European Committee for Standardization; 2006.
20. Gonçalez JC, D’Ambros J, Ribeiro PG, Garcez LRO. Tratamento térmico aplicado a três espécies de madeiras e a um tipo de painel MDF. In: Anais. Congresso Florestal; 2014.

21. Tjeerdsma BF, Stevens M, Militiz H. Durability aspects of (hydro) thermal treated wood. International Research Group on Wood Preservation. Kona; 2000. Available from: <http:// www.irg-wp.com/irgdocs/details.php?889aae2c-dc26-4b55a8a5-eb699957bfcf $>$. Access in: 29/11/2016.

22. Figueroa MJM, Moraes PD. Comportamento da madeira a temperaturas elevadas. Ambiente Construído. 2009;9(4):157-174.

23. Cavdar AD, Ertaş M, Kalaycıoğlu H, Alma MH. Some properties of thin medium density fiberboard panels treated with sunflower waste oil vapor. Materials \& Design (1980-2015). 2010;31(5):2561-2567.

24. Tjeerdsma BF, Militz H. Chemical changes in hydrothermal treated wood: FTIR analysis of combined hydrothermal and dry heattreated wood. Holz als Roh- und Werkstoff. 2005;63(2):102-111.

25. Yildiz S, Gümüşkaya E. The effect of termal modification on crystalline structure of cellulose in soft and hardwood. Building and Environment. 2007;42(1):62-67.

26. Hillis WE. Wood quality and utilization. Eucalyptus for wood production. Melbourne: CSIRO/Academic Press; 1984.

27. Mohebby B, Ilbeighi F. Physical and mechanical properties of hydrothermally modified medium density fiberboard (MDF). In: Proceedings of the International Panel Products Symposium 2007; 2007 Oct 17-19; Cardiff, Wales. p. 341-348.

28. American National Standard. ANSI A208.2. Medium density fiberboard for interior use.. National particleboard assoc. Gaithersburg: American National Standard; 2002.

29. Eleotério JR, Tomazallo Filho M, Bortoletto Júnior G. Propriedades físicas e mecânicas de painéis MDF de diferentes massas específicas e teores de resina. Ciência Florestal. 2000;10(2):75-90.

30. Ganev S, Gendron G, Cloutier A, Beauregard R. Mechanical properties of MDF as a function of density and moisture content. Wood and Fiber Science. 2005;37(2):314-326.

31. Rowell RM, ed. Handbook of wood chemistry and wood composites. $1^{\text {st }}$ ed. Boca Raton: CRC Press; 2005. 504 p.

32. Shi JL, Kocaefe D, Zhang J. Mechanical behaviour of Quebecwood species heat-treated using ThermoWood process. Holz als Rohund Werkstoff. 2007;65(4):255-259.

33. Jarusombuti S, Ayrilmis N, Bauchongkol P, Fueangvivat V. Surface characteristics and overlaying properties of MDF panels made from thermally treated rubberwood fibers. BioResources. 2010;5(2):968-978. 